\title{
IMPLEMENTASI PERATURAN PEMERINTAH NOMOR 19 TAHUN 2008 TENTANG KECAMATAN
}

\section{The Implementation Of Government Regulation No. 19/2008 About Sub District}

\author{
Hasoloan Nadeak \\ Pusat Penelitian Pemerintahan Umum dan Kependudukan \\ Badan Penelitian dan Pengembangan Kementerian Dalam Negeri \\ Jl. Kramat Raya No. 132 -Senen, Jakarta \\ e-mail: hnadeaklit@gmail.com, Tlp.08216390 6021
}

Dikirim: 13 Juli 2014; direvisi: 20 Agustus 2014; disetujui: 2 September 2014

\begin{abstract}
Abstrak
Tujuan penelitian ini adalah untuk mengetahui dan menganalisis implementasi kebijakan tentang kecamatan di kota Bogor; untuk mengetahui dan menganalisis dukungan juklak dan juknis yang ditetapkan terhadap tugas-tugas Camat dan perangkat kecamatan yang ada di kota Bogor; dan untuk mengetahui dan menganalisis kinerja kebijakan setelah diimplementasikan para camat dan perangkat kecamatan di wilayahnya masing-masing. Implementasi Peraturan Pemerintah Nomor 19 Tahun 2008 tentang kecamatan adalah suatu keharusan, karena Peraturan Pemerintah dimaksud adalah peraturan pelaksanaan yang berlaku secara nasional dan diamanatkan Undang-undang Nomor 32 Tahun 2004 tentang Pemerintahan Daerah. Pendekatan yang digunakan untuk melihat permasalahan dimaksud adalah deskriptif kualitatif dengan metode content analysis atau document analysis. Berdasarkan pendekatan dimaksud diketahui bahwa Pemerintah Kota Bogor telah mengimplementasikan PP No.19 Tahun 2008 ke dalam bentuk Peraturan Walikota No. 54 Tahun 2010 tentang Tugas Pokok, Fungsi, Tata Kerja dan Uraian Tugas Jabatan Struktural di lingkungan Kecamatan dan Nomor 10 Tahun 2010 tentang Pelimpahan Kewenangan. Pengimplemantasian kebijakan dimaksud meliputi: (1) Tugas Umum Pemerintahan, dan (2) Sebagian tugas yang dilimpahkan oleh Walikota kepada Camat dalam kaitan otonomi daerah. Kata kunci: Implementasi kebijakan, tugas umum pemerintahan dan tugas yang dilimpahkan.
\end{abstract}

\begin{abstract}
The purpose of this study was to determine and analyze the implementation of the policy of districts in the city of Bogor; to determine and analyze the technical and operational guidelines support the tasks assigned to the sub-district and the districts in the city of Bogor; and to determine and analyze the performance of the policy after the implementation of the district and sub-district in each region. Implementation of Government Regulation Number 19 Year 2008 concerning the sub-district is a must, because of government regulation in question is the implementing regulations that apply nationally and mandated by Law No. 32 of 2004 on Regional Government. The approach used to look at the problem in question is descriptive qualitative content analysis or document analysis. Based approach is known that the City Government has implemented PP No. 19 of 2008 in the form of Mayor Regulation No. 54 Year 2010 on Main Duties, Functions, Duties Work Procedures and structural positions within the District and No. 10 of 2010 on Delegation of Authority. The implementation of policy shall include: (1) Common Tasks Government, and (2) Some tasks are delegated by the Mayor of the District Head in terms of regional autonomy.

Keywords: Implementation of policies, common tasks and delegated administration.
\end{abstract}

\section{PENDAHULUAN}

Peraturan Pemerintah atau disingkat PP adalah peraturan pelaksanaan yang diamanatkan UndangUndang. Demikian juga halnya dengan PP Nomor 19 Tahun 2008 tentang Kecamatan adalah merupakan peraturan pelaksanaan yang berlaku secara nasional dan diamanatkan oleh Undang-Undang Nomor 32 Tahun 2004 tentang Pemerintahan Daerah (UU No. 32/2004) secara garis besar Pasal 126 mengatur halhal seperti:

1. Kecamatan dibentuk di wilayah kabupaten/kota dengan Perda berpedoman pada Peraturan Pemerintah, dan dipimpin camat, yang dalam pelaksanaan tugasnya memperoleh pelimpahan sebagian wewenang bupati atau walikota untuk menangani sebagian urusan otonomi daerah.

2. Selain tugas dimaksud, camat juga menyelenggarakan tugas umum pemerintahan, meliputi:

a. Mengkoordinasikan kegiatan pemberdayaan masyarakat;

b. Mengkoordinasikan upaya penyelenggaraan ketentraman dan ketertiban umum;

c. Mengkoordinasikan penerapan dan penegakan peraturan perundang-undangan;

d. Mengkoordinasikan pemeliharaan prasa-rana dan fasilitas pelayanan umum;

e. Mengkoordinasikan penyelenggaraan kegiatan pemerintahan di tingkat kecamatan; 
f. Membina penyelenggaraan pemerintahan desa dan/atau kelurahan;

g. Melaksanakan pelayanan yang menjadi ruang lingkup tugasnya dan/atau yang belum dapat dilaksanakan pemerintahan desa atau kelurahan.

Sebagai tindak lanjut dari ayat (7) di atas, sekaligus sebagai pedoman bagi bupati dan walikota dalam menetapkan peraturan bupati/walikota dalam mengatur dan menata kecamatan yang ada di daerahnya, maka ditetapkan Peraturan Pemerintah Nomor 19 Tahun 2008 tentang Kecamatan, dan secara sistematis PP ini disusun dalam tiga belas bab dan tiga puluh delapan pasal. Artinya, berdasarkan ayat (7) Pasal 126 UU No. 32/2004 tersebut, para bupati/walikota seluruh Indonesia diamanatkan untuk melaksanakan atau mengimplementasikan PP No.19 Tahun 2008 tentang Kecamatan di wilayah masingmasing.

Pelaksanaan atau pengimplementasian PP dimaksud, di samping sebagai dasar hukum bagi para bupati/walikota seluruh Indonesia untuk menata kecamatan dalam menyelenggarakan tugas umum pemerintahan, juga para bupati/walikota diwajibkan melimpahkan sebagian wewenangnya kepada camat untuk menangani sebagian urusan otonomi daerah.

Apabila diperhatikan secara cermat, pelaksanaan atau pengimplementasian Pasal 18 dan Pasal 18A UUD NKRI 1945 di dalam UU No. 32 Tahun 2004 tentang Pemerintahan Daerah, dalam Pasal 126 mengamanatkan bahwa "Kecamatan dipimpin camat, yang dalam pelaksanaan tugasnya memperoleh pelimpahan sebagian wewenang bupati/walikota untuk menangani sebagian urusan otonomi daerah". Untuk melaksanakan amanat tersebut "ditetapkan dengan Peraturan Bupati/Walikota dengan berpedoman pada Peraturan Pemerintah", (Pasal 126 UU No. 32 Tahun 2004).

Artinya, bahwa tindak lanjut dari Pasal 126 ayat (7) UU No. 32 Tahun 2004 dimaksud harus ditetapkan kedalam suatu Peraturan Pemerintah tentang Kecamatan, dalam hal ini Peraturan Pemerintah (PP) No. 19 Tahun 2008 tentang Kecamatan, PP inilah yang menjadi dasar hukum bagi para bupati/walikota seluruh Indonesia untuk menata kecamatan di daerahnya masing-masing.

Akan tetapi secara empiris masalah implementasi kebijakan tidak semudah membalikkan telapak tangan, implementasi kebijakan merupakan suatu kegiatan yang begitu kompleks ${ }^{1}$ seperti: melibatkan banyak aktor dengan berbagai kepentingan mereka masing-masing, kebijakan yang diimplementasikan tidak dirumuskan secara jelas. Bahkan Hogwood dan Gunn (1984) dalam Purwanto dan Sulistyastuti (2012) mengatakan "perfect implementation" tidak pernah terwujud karena beberapa hal, yaitu: 1) Ada hambatan kondisi eksternal; b) Waktu dan sumber daya tidak tersedia secara memadai; 3) hubungan antara sebab akibat antara kebijakan dan hasilnya jarang bersifat langsung; 4) lembaga pelaksana jarang yang bisa mandiri. Kondisi ini paling tidak dapat diindikasikan hasil penelitian Puslitbang Pembangunan dan Keuangan Daerah Balitbang Kemendagri tahun 2011, bahwa dari delapan kecamatan di Kabupaten/Kota dan Provinsi yang berbeda empat diantaranya belum mengimplementasikan PP No. 19/2008. Dalam kaitan inilah penelitian dilakukan dengan judul Implementasi Peraturan Pemerintah Nomor 19 Tahun 2008 tentang Kecamatan dengan lokasi di Kota Bogor.

Untuk mengetahui apa dan bagaimana implementasi PP No. 19/2008 dimaksud, perlu terlebih dahulu dirumuskan permasalahannya, karena "masalah yang dirumuskan dengan baik adalah masalah yang setengah terpecahkan."2 Oleh karena itu, untuk merumuskan permasalahannya beberapa hal penting diperhatikan yaitu: pertama, rentang waktu penetapan PP No. 19/2008 yang cukup lama yaitu 3 tahun 4 bulan, dihitung sejak diundangkannya UU No. 32/2004 sebagai induknya (Oktober 2004), sedangkan PP No. 19 Tahun 2008 (Pebruari 2008) baru ditetapkan, kedua, secara derivatif PP No. 19/2008 juga mengamanatkan paling tidak lima (5) Peraturan Menteri Dalam Negeri (Permendagri) sebagai petunjuk pelaksanaan atau petunjuk teknis (juklak \& juknis), sebagaimana terdapat dalam pasal-pasal dalam batang tubuh PP No. 19 Tahun 2008 yaitu: Pasal 23 ayat (3), Pasal 26 ayat (2), Pasal 29 ayat (4), Pasal 32 ayat (3), dan Pasal 36.

Di samping kelima pasal di atas yang harus ditetapkan dalam bentuk Permendagri, juga ada Permendagri No.4 Tahun 2010 yang mengatur secara teknis tentang Pedoman Pelayanan Terpadu di Kecamatan. Dengan demikian, permasalahan dalam penelitian ini adalah:

1. Apakah kebijakan tentang kecamatan yang diatur dalam PP No. 19 Tahun 2008 telah diimplementasikan oleh Pemerintah Kota Bogor ke dalam bentuk Peraturan Daerah (Perda) atau Peraturan Walikota Bogor dan dilaksanakan oleh para camat yang ada di wilayah kota Bogor?

2. Apakah juklak dan juknis yang ditetapkan dalam bentuk Permendagri mendukung pelaksanaan tugas-tugas camat dan perangkatnya?

3. Bagaimana kinerja kebijakan setelah diimplementasikan?

Bertitik tolak dari rumusan permasalahan yang dikemukakan di atas, maka tujuan penelitian adalah: 1) untuk mengetahui dan menganalisis implementasi kebijakan tentang kecamatan di kota Bogor; 2) untuk mengetahui dan menganalisis dukungan juklak dan juknis yang ditetapkan terhadap tugas-tugas Camat dan perangkat kecamatan yang ada di kota Bogor; 3) untuk mengetahui dan menganalisis kinerja kebijakan setelah diimplementasikan para camat dan perangkat kecamatan di wilayahnya masing-masing.

Dalam berbagai literatur mengenai kebijakan publik telah banyak mengemukakan berbagai definisi kebijakan publik, baik dalam arti yang luas maupun dalam pengertian yang sempit. Young dan Quinn 


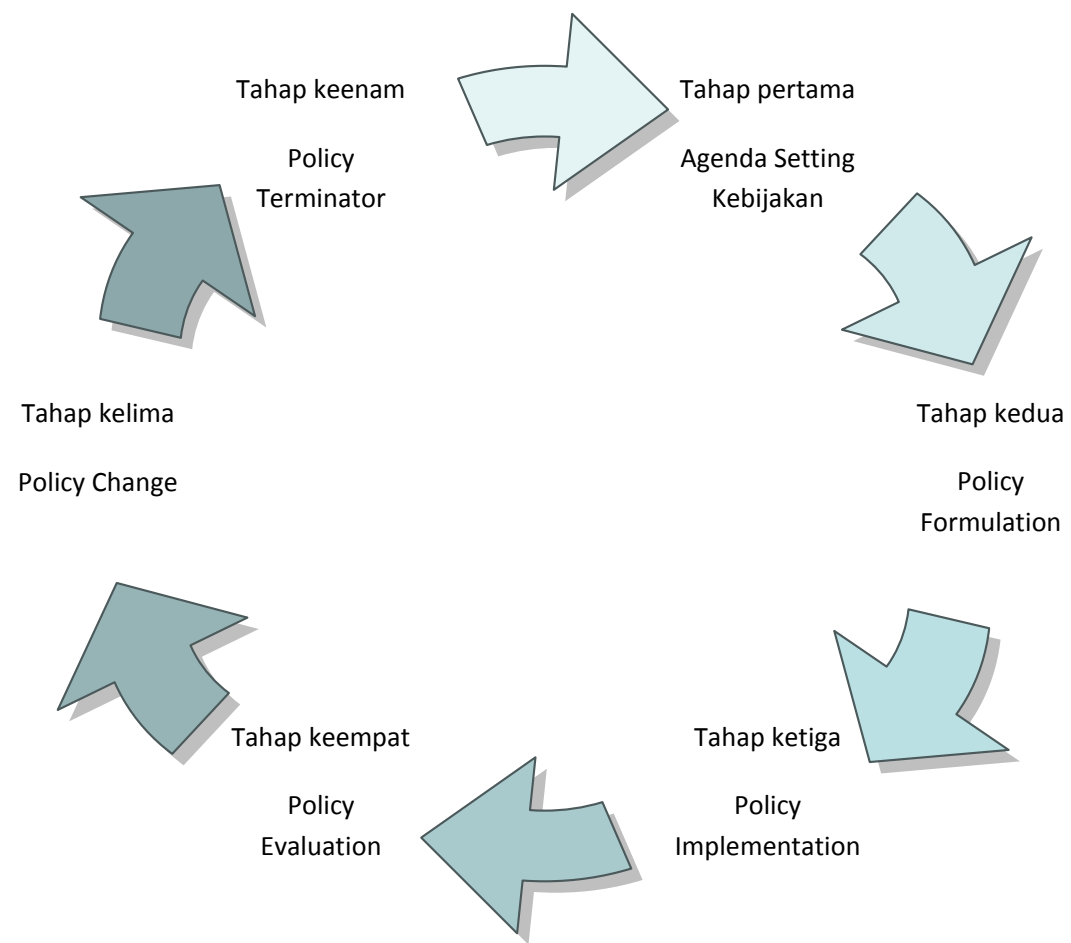

Gambar 1. Proses Perumusan Kebijakan Publik Lister dan Stewart (2005:5) dalam Purwanto \& Sulistyastuti (2012:23)

(2002:5) dalam Suharto (2012:44) memberikan definisi kebijakan publik secara luas yaitu: "What governments choose to do or to do". Sementara itu, Anderson dalam Suharto (2012) mengemukakan definisi kebijakan publik yang relatif lebih spesifik, yaitu: "a purposive course of action follow by an action or set of actors in dealing with a problem or matter of concern". Sedangkan Suharto (2012) menjelaskan berbagai definisi kebijakan sebagai berikut:

1. Kebijakan publik adalah merupakan tindakan pemerintah, yang dibuat dan diimplementasikan oleh badan pemerintah yang memiliki kewenangan hukum, politis dan finansial untuk melakukannya.

2. Kebijakan publik adalah sebuah reaksi terhadap kebutuhan dan masalah dunia nyata yang berupaya merespons masalah atau kebutuhan kongkrit yang berkembang di masyarakat.

3. Kebijakan publik adalah seperangkat tindakan yang berorientasi pada tujuan dan bukan merupakan keputusan tunggal, melainkan terdiri dari beberapa pilihan tindakan atau strategi yang dibuat untuk mencapai tujuan tertentu demi kepentingan orang banyak.

Pengertian atau definisi kebijakan publik seperti dijelaskan, adalah merupakan "tindakan pemerintah", "sebuah reaksi terhadap masalah", dan "seperangkat tindakan", ini menunjukan bahwa kebijakan publik itu mempunyai proses, seperti dikemukakan pada Gambar 1.

Berangkat dari gambar proses Perumusan Kebijakan Publik tersebut, kebijakan publik mempunyai dua tahapan yaitu agenda setting kebijakan dan formulasi kebijakan, sedangkan implementasi kebijakan adalah merupakan tahap ketiga.

Tahap agenda setting kebijakan mengindikasikan bahwa setiap kebijakan publik yang dirumuskan memang akan selalu dimulai dari adanya suatu masalah publik, yang mendapat perhatian luas yang menuntut tindakan pemerintah untuk memecahkan masalah tersebut melalui suatu kebijakan.

Setelah tahap agenda setting selesai dilanjutkan dengan formulasi kebijakan yang merupakan proses perumusan rencana serta metode untuk menyelesaikan permasalahan yang ada dalam agenda setting. Tahap selanjutnya adalah implementasi. Implementasi kebijakan dalam gambar di atas adalah tahap ketiga, yang mempunyai paling tidak tiga komponen dasar yaitu: 1) tujuan yang luas; 2) sasaran yang spesifik; dan 3) cara mencapai sasaran, (Wibawa dkk, 1994:15). Tahap keempat dan kelima adalah evaluasi kebijakan dan penyempurnaan, yang terakhir adalah kebijakan yang dihentikan apabila tujuan yang diinginkan sudah berhasil dicapai.

Berbagai penulis mendefinisikan Implementasi Kebijakan, dalam kaitan penelitian ini tidak semua dijelaskan definisi dimaksud. Penulis tersebut misalnya: Implementasi kebijakan menurut model Grindle, menurut model Meter dan Horn, menurut model Sabatier dan Mazmaniam. Sebagai contoh model implementasi kebijakan dapat dikemukakan menurut model Sabatier dan Mazmaniam.

Implementasi kebijakan model Sabatier dan Mazmanian (1986) dalam Wibawa (1994), 
menjelaskan bahwa "Implementasi kebijakan merupakan fungsi dari tiga variabel, yaitu: 1) karakteristik masalah; 2) struktur manajemen program yang tercermin dalam berbagai macam peraturan yang mengoperasionalkan kebijakan; 3) faktor-faktor di luar peraturan, sebagaimana dapat dilihat dalam Lampiran Gambar 8.

Setelah semua terpenuhi seperti model implementasi kebijakan yang terdapat dalam gambar, maka pada tahap implementasinya para pejabat pelaksana dan kelompok sasaran harus mematuhi program, tanpa kepatuhan para pejabat pelaksana, tujuan kebijakan tidak akan tercapai. Keharusan tersebut menyiratkan sebuah pengakuan bahwa meskipun formulasi kebijakan telah dirumuskan sebelumnya melalui proses bargaining, konflik, maupun persuasi, tidak berarti para pelaku menghentikan kegiatannya ketika kebijakan mulai diimplementasikan.

Selanjutnya, pengertian implementasi kebijakan menurut Wibawa, dkk (1994:15), selalu mengandung paling tidak tiga komponen dasar yaitu: 1) tujuan yang luas; 2) sasaran yang spesifik; 3) cara mencapai sasaran.

Komponen cara mencapai sasaran-sasaran biasanya belum dijelaskan secara rinci, itulah sebabnya birokrasi menyebut sebagai programprogram aksi dan proyek. Di dalam "cara mencapai sasaran” (Wibawa, dkk), menyatakan “....terkandung beberapa komponen kebijakan yang lain, yakni: siapa pelaksana atau implementornya, berapa besar dan dari mana dana diperoleh, siapa kelompok sasarannya, bagaimana program dilaksanakan atau bagaimana sistem manajemennya dan bagaimana keberhasilan atau kinerja kebijakan diukur.

Dengan demikian, komponen cara mencapai sasaran dari suatu kebijakan merupakan komponen yang berfungsi untuk mewujudkan dua komponen sebelumnya, yaitu tujuan dan sasaran khusus. Cara untuk mewujudkan tujuan dan sasaran khusus inilah sebagai implementasi kebijakan.

Sebagai suatu tindakan yang akan dilakukan untuk mencapai tujuan sebagaimana dirumuskan dalam suatu kebijakan, maka kerangka pikir penelitian ini dapat dikemukakan dalam Gambar 2.

Mengacu pada pengertian-pengertian teoritis yang dipaparkan sebelumnya, maka kerangka konsep dalam penelitian ini dapat ditarik dari pengertianpengertia teoritis dimaksud yaitu: pertama, bahwa kebijakan publik atau kebijakan negara adalah rangkaian konsep atau asas yang menjadi garis besar dan dasar rencana dalam pelaksanaan suatu pekerjaan, kepemimpinan dan cara bertindak baik dalam penyelenggaraan pemerintahan maupun organisasi atau kelembagaan. Kebijakan sebagai asas yang menjadi garis besar atau dasar dalam pelaksanaan suatu pekerjaan dari suatu oganisasi lembaga, maka kebijakan itu dapat berbentuk:
1. Pernyataan cita-cita, tujuan, prinsip dan maksud sebagai garis pedoman untuk manajemen dalam usaha mencapai sasaran.

2. Tindakan pemerintah mengenai sesuatu masalah tertentu dalam arti positif dan juga merupakan keputusan pemerintah untuk tidak melakukan sesuatu dalam arti negatif. Kebijakan positif selalu dilandaskan pada peraturan-peraturan perundangundangan yang sifatnya memaksa.

3. Taktik atau strategi untuk memecahkan masalah atau untuk mencapai tujuan. Jadi, kebijakan negara itu selalu mempunyai tujuan tertentu atau merupakan tindakan yang berorientasi pada tujuan, sehingga kebijakan itu berisi tindakan-tindakan atau pola-pola tindakan pejabat-pejabat pemerintah.

Kedua, kebijakan sebagai suatu strategi, pernyataan cita-cita maupun tindakan, perlu dilakukan evaluasi kebijakan atau penilaian kebijakan guna mengetahui:

1. Bagaimana dan mengapa terjadi perbedaan antara kebijakan yang ditetapkan dengan fakta di lapangan (hasil kebijakan)

2. Sejauhmana kebijakan itu memberi sumbangan pada tujuan dan sasaran

3. Bagaimana tingkat keberhasilan program aksi atau proyek dalam mencapai tingkat kinerja yang bermakna, dalam mengatasi masalah yang dihadapi.

Dalam praktiknya evaluasi kebijakan/ penilaian kebijakan, mencakup tiga hal yakni: 1.) isi kebijakan; 2) pelaksanaan/implementasi kebijakan; dan 3) dampak kebijakan.

Ketiga, Implementasi kebijakan. Kebijakan publik itu secara umum memuat tiga hal penting yaitu: 1) tujuan yang luas; 2) sasaran spesifik; 3) cara mencapai tujuan atau sasaran. Komponen cara mencapai tujuan atau sasaran adalah merupakan komponen yang berfungsi untuk mewujudkan tujuan dan sasaran khusus (spesifik). Cara untuk mewujudkan tujuan dan sasaran inilah yang disebut dengan implementasi kebijakan. Dengan demikian implementasi kebijakan adalah cara atau metode untuk mencapai tujuan atau sasaran, dan sebagai metode maka harus ada model. Secara teoritis ada empat (4) model yang dikemukakan contohnya sebagaimana telah dijelaskan di atas.

Kesimpulan yang dapat ditarik dari penjelasanpenjelasan yang dipaparkan adalah bahwa efektivitas implementasi kebijakan ditentukan oleh perilaku birokrasi pelaksanaannya. Bertitik tolak dari penjelasan-penjelasan dan kerangka konsep, maka di bawah ini dikemukakan kerangka penelitian seperti pada Gambar 3.

Kerangka penelitian seperti gambar di atas, yang akan dikembangkan sebagai indikator, yang selanjutnya dituangkan dalam bentuk instrument penelitian. 


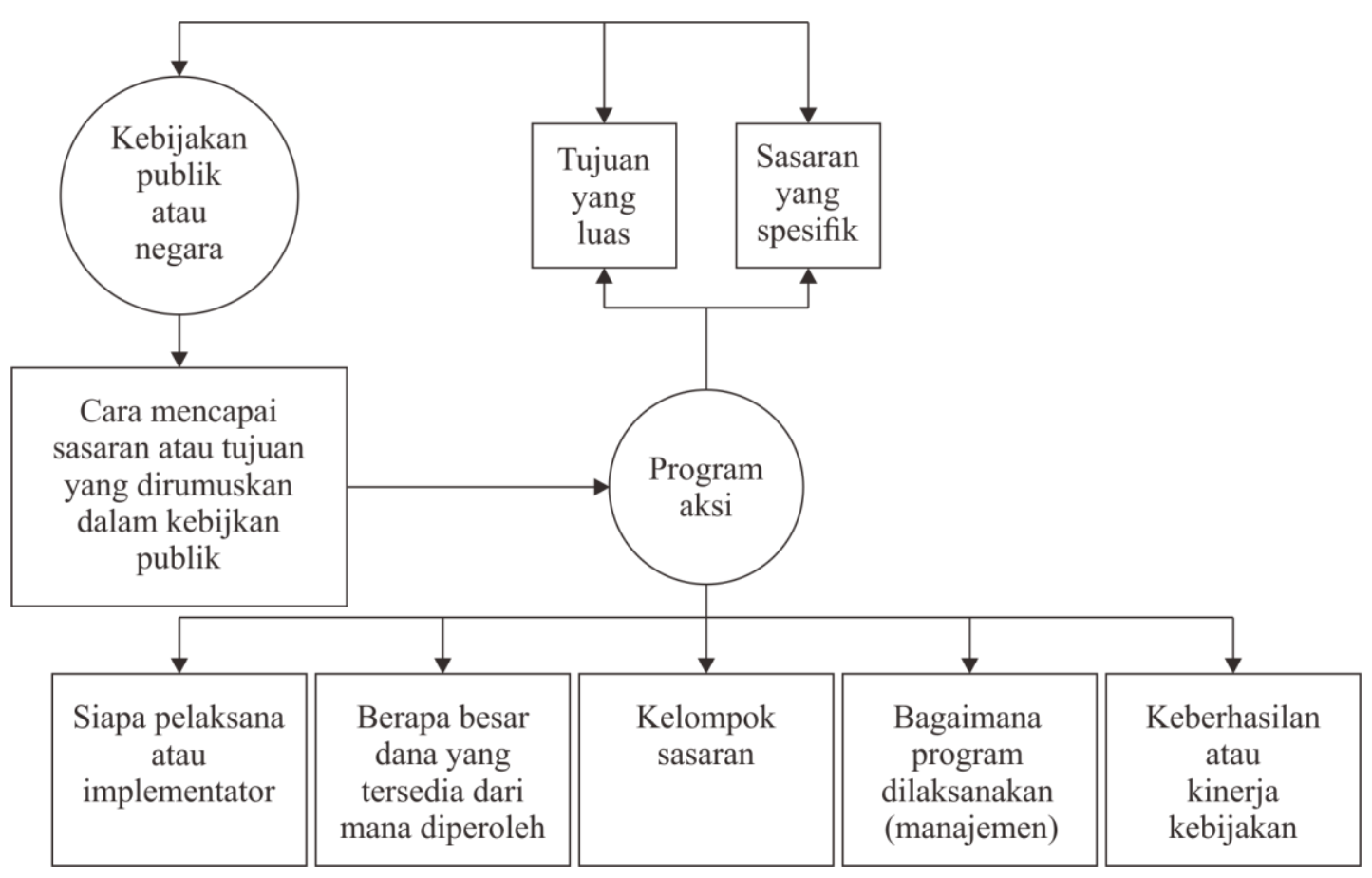

Gambar 3. Kerangka penelitian

\section{METODE PENELITIAN}

\section{Metode Penelitian}

Penelitian yang dilaksanakan adalah termasuk bagian dari Penelitian Kebijakan (Policy Research). Dengan demikian, metode yang digunakan dalam penelitiannya adalah metode Analisis Dokumen atau Content Analysis (Analisis Isi) dengan jenis penelitiannya yaitu deskriptif kualitatif.

Melalui metode penelitian dokumen ini hendak melakukan penelusuran atau telaahan dokumen terutama yang menyangkut penerapan (implementasi kebijakan tentang kecamatan yang ditetapkan dalam PP No. 19 Tahun 2008).

\section{Lokasi Penelitian}

Penelitian ini dilaksanakan di Kota Bogor, tepatnya di tiga (3) dari enam (6) kecamatan yang ada di kota Bogor. Adapun alasan pemilihan lokasi penelitian ini adalah:

a. Alasan geografis

Sebagaimana diketahui letak geografis berpengaruh terhadap penyelenggaraan pemerintahan, terutama dalam hal penyediaan transportasi.

Wilayah Kota Bogor merupakan kawasan yang sudah terbangun dengan berbagai jenis pemanfaatannya yaitu: 1) seluas 4.151,69 Ha atau $35,48 \%$ kawasan pemukiman; 2) seluas $2.112,72 \mathrm{Ha}$ atau 2,40\% untuk lahan pertanian; 3) seluas 92,59 Ha atau $1,42 \%$ untuk lahan industry; 4) seluas $81,02 \mathrm{Ha}$ atau $3,69 \%$ untuk perdagangan dan jasa; 5) seluas $90,02 \mathrm{Ha}$ atau $0,76 \%$ untuk perkantoran dan pemerintahan; 6) seluas $141,50 \mathrm{Ha}$ atau $1,19 \%$ merupakan hutan kota; 7) seluas 342,33 Ha atau $2,89 \%$ untuk taman dan lapangan olah raga; 8) seluas $305,96 \mathrm{Ha}$ atau 2,58\% untuk lahan kuburan; dan 9) seluas 342,07 atau 2,89\% merupakan sungai dan situ.

b. Alasan Demografis

Jumlah penduduk Kota Bogor tahun 2010 sebanyak 950.334 jiwa (sensus Penduduk tahun 2010), yang terdistribusi ke enam wilayah kecamatan. Di samping itu jumlah wilayah kecamatan dalam satu kota relatif banyak yaitu enam kecamatan.

\section{Informan Penelitian}

Informan dalam penelitian ditetapkan berdasarkan metode purposive sampling, yaitu: a. Untuk tingkat Kota Bogor, yang menjadi informannya adalah Kepala Bagian Pemerintahan Kota Bogor., b. Untuk tingkat kecamatan, yang menjadi informan adalah Camat.

\section{Teknik Pengumpulan Data dan Pengolahan Data}

a. Tehnik Pengumpulan Data

Penelitian ini membutuhkan dua (2) jenis data, pertama, data sekunder yang diperoleh melalui studi kepustakaan dan dokumen yang ada kaitannya dengan kecamatan, kedua, data primer yang diperoleh melalui kuesioner yang disampaikan kepada informan.

\section{b. Tehnik Pengolahan Data}

Setelah data terkumpul melalui metode yang digunakan, selanjutnya data tersebut diolah dengan langkah-langah sebagai berikut: 
1. Melakukan editing seperti kelengkapan data, kebenarannya dan ketepatannya serta relevansi dengan variabel penelitian.

2. Menyeleksi data untuk selanjutnya di kelompokkan bedasarkan variabel dan indikator.

3. Membuat tabulasi data yang diformulasikan ke dalam tabel, berdasarkan tabulasi data inilah dibuat analisis.

\section{Teknik Analisis}

Sesuai tujuan penelitian ini yaitu untuk melihat dan mengkaji kebijakan yang implementatif tentang kecamatan, yang lebih fokus pada tujuan yang luas, sasaran yang spesifik dan cara mencapai sasaran serta bagaimana program aksinya ke masa depan, maka teknik analisis dalam penelitian ini digunakan pendekatan Dassolen dan Dassein atau seharusnya (dassolen) dan kenyataannya (dassein).

Artinya, seharusnya PP No. 19 Tahun 2008 sudah diimplementasikan, kenyataannya, bagaimna di Kota Bogor, seharusnya ada tujuan atau sasaran yang hendak dicapai bagaimana faktanya di wilayah kecamaatan di Kota Bogor.

\section{HASIL DAN PEMBAHASAN}

Sebagaimana telah dikemukakan sebelumnya, bahwa suatu kebijakan itu paling tidak memuat tiga (3) hal penting, yaitu: a) ada tujuan yang luas, b) ada tujuan yang spesifik, dan c) ada cara untuk mencapai/mewujudkan kedua tujuan dalam kebijakan yang ditetapkan tersebut. Terkait dengan kebijakan tentang tentang kecamatan yang ditetapkan dalam bentuk Peraturan Pemerintah No.19 Tahun 2008, maka dapat dikemukakan pembahasannya sebagai berikut:

\section{Tujuan yang luas}

Tidak mudah menyatakan atau menjelaskan tujuan spesifik apalagi tujuan yang luas suatu kebijakan, terlebih-lebih apabila tidak dicantumkan atau tidak diatur secara jelas dalam naskah kebijakan itu sendiri. Demikianlah halnya dengan PP No. 19 Tahun 2008 sebagai kebijakan yang mengatur tentang kecamatan, tujuan spesifik dan tujuan yang luas tidak diatur atau disebutkan secara eksplisit. Meskipun demikian, tidaklah berarti PP No. 19 Tahun 2008 tentang kecamatan tidak mempunyai tujuan yang luas dan tujuan yang spesifik. Hal ini dapat dilihat atau dibaca dalam diktum pertimbangan dan penjelasan umum PP No. 19 Tahun 2008 itu sendiri.

Dalam penjelasan umum PP No. 19 Tahun 2008 dengan sangat jelas disebutkan "Camat dalam menjalankan tugasnya mendapatkan pelimpahan kewenangan dari dan bertanggung jawab kepada bupati/walikota dan mengemban penyelenggaraan tugas-tugas umum pemerintahan". Artinya, camat melaksanakan tugas pelimpahan dari Bupati/Walikota dalam rangka otonomi daerah dan melaksanakan tugas-tugas umum pemerintahan, inilah tujuan yang luas dari PP No, 19 Tahun 2008, yang tidak pernah berakhir meskipun dilaksanakan.

Kedua tugas yang dilaksanakan Camat tersebut merupakan akibat dari implementasi kebijakan

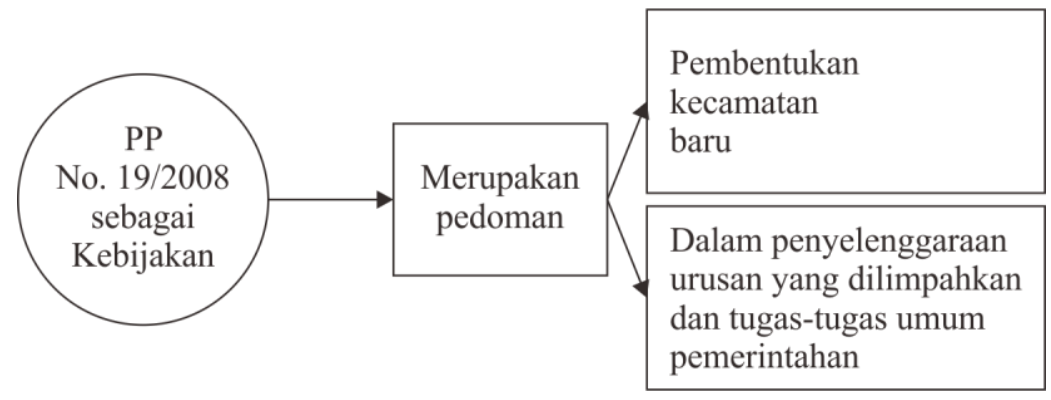

Gambar 4: Tujuan Spesifik PP No.19/2008

Tabel 1. Implementasi PP No. 19 Tahun 2008 dari 8 wilayah provinsi sampel

\begin{tabular}{llllcc}
\hline \multirow{2}{*}{ No } & \multicolumn{1}{c}{ Provinsi } & \multirow{2}{*}{ Kabupaten/Kota } & \multicolumn{2}{c}{ Kecamatan } & \multicolumn{2}{c}{ Keterangan } \\
\cline { 5 - 6 } & & & & Sudah & Belum \\
\hline 1. & Papua Barat & Kab. Manokwari & Manokwari Barat & - & $\sqrt{ }$ \\
2. & NTB & Kota Mataram & Kec. Mataram & - & $\sqrt{ }$ \\
3. & Jatim & Suarabaya & Kec. Rungkut & $\sqrt{ }$ & - \\
4. & DI. Yogyakarta & Kota Yogyakarta & Kec. Umbulharjo & $\sqrt{ }$ & - \\
5. & Jateng & Kota Semarang & Semarang Selatan & - & $\sqrt{ }$ \\
6. & Sumut & Kota Medan & Medan Tembung & $\sqrt{ }$ & - \\
7. & Banten & Kota Serang & Kec. Serang & $\sqrt{ }$ & - \\
8. & Jabar & Kota Bandung & Bandung Barat & - & $\sqrt{ }$ \\
\hline
\end{tabular}

Sumber: Hasil nenelitian Pusat Lithang Pembangunan \& Keuangan Daerah tahun 2011. 
otonomi daerah sebagaimana diatur dalam UU No.32 Tahun 2004 tentang Pemerintahan Daerah yang merupakan sumber hukum dari PP No. 19 Tahun 2008 tersebut. Implementasi kebijakan otonomi daerah ini telah mendorong terjadinya perubahan, baik secara struktural, fungsional maupun kultural dalam tatanan penyelenggaraan pemerintahan daerah.

Salah satu perubahan yang sangat esensial yaitu menyangkut kedudukan, tugas pokok dan fungsi kecamatan yang sebelumnya merupakan perangkat wilayah dalam kerangka asas dekonsentrasi berubah menjadi perangkat daerah dalam kerangka asas desentralisasi. Sebagai perangkat daerah Camat dalam menjalankan tugasnya mendapat pelimpahan kewenangan dari dan bertanggung jawab kepada bupati/walikota dan juga mengemban penyelenggaraan tugas-tugas umum pemerintahan.

\section{Tujuan yang Spesifik}

Adapun tujuan spesifik dari kebijakan PP No. 19 Tahun 2008 adalah sebagai "Pedoman dalam pembentukan kecamatan dan penyelenggaraan urusan pemerintahan di kecamatan", (diktum pertimbangan PP No.19/2008). Sebagai tujuan spesifik, ada dua kegiatan yang dilakukan dan harus mengacu atau berpedoman pada PP No. 19 Tahun 2008; kedua kegiatan dimaksudn adalah: pertama, apabila hendak membentuk satuan/unit kerja kecamatan yang baru (pemekaran) harus berpedoman pada PP Nomor 19 Tahun 2008, kedua, semua satuan/unit kerja kecamatan dalam penyelenggaraan urusan pemerintahan di kecamatan harus mengacu pada PP No. 19 Tahun 2008.

Jadi, apabila digambarkan secara sederhana, tujuan spesifik PP No. 19/ 2008 tampak pada Gambar 4. Meskipun PP No. 19 Tahun 2008 sebagai kebijakan yang harus dipedomani, namun sampai tahun 2011 lalu belum semua kabupaten dan kota menimplementasikan PP No.19 Tahun 2008. Artinya, belum semua bupati/walikota menetapkan peraturan bupati bupati/walikota yang mengacu pada PP dimaksud dalam mengatur Tugas Pokok dan Fungsi kecamatan. Sesuai hasil penelitian Puslitbang Pembangunan \& Keuangan Daerah (2011) dari

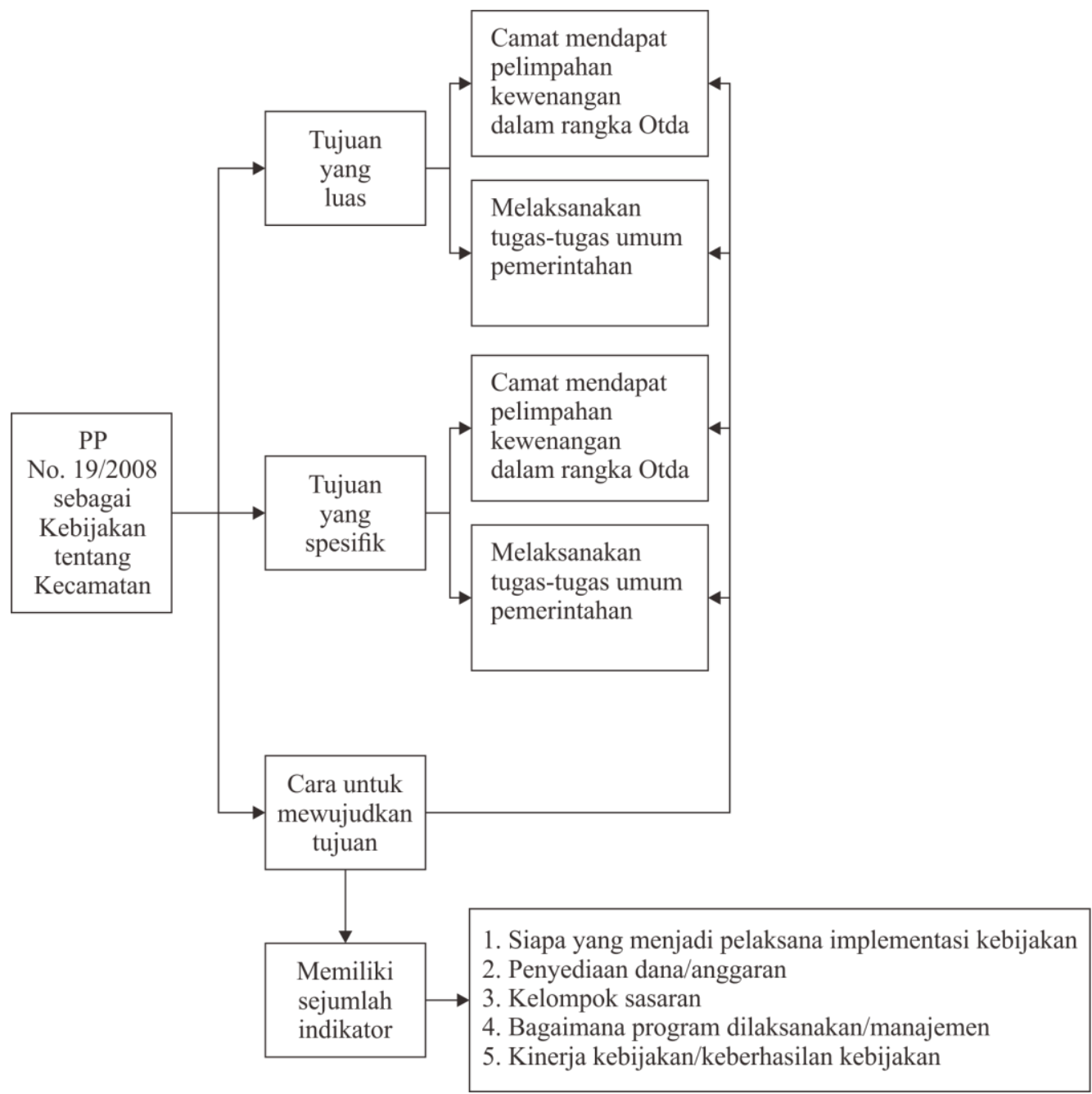

Gambar 5: Proses pencapaian tujuan kebijakan sebagai wujud implementasi kebijakan 
delapan (8) wilayah kecamatan di berbagai provinsi baru empat kabupaten/kota yang sudah mengimplementasikannya. Hasil selengkapnya penelitian dimaksud dapat dikemukakan dalam Tabel 1.

Faktor penyebab PP No.19/2008 belum diimplementaskan oleh Bupati/ Walikota seperti disebutkan di atas adalah:

1. Untuk Kab. Manokwari belum ada sosialisasi dari Provinsi Papua Barat.

2. Untuk Kota Mataram karena sedang menghadapi Pemilukada Walikota.

3. Untuk Kota Semarang dan Kota Bandung, dalam proses pembahasan/ penyusunan.

Sedangkan untuk Kota Bogor PP No.19/2008 telah diimplementasikan ke dalam Peraturan Walikota Bogor No.54 Tahun 2008 tentang Tugas Struktural di lingkungan Kecamatan dan Peratruan Walikota No. 1 Tahun 2011 tentang Pelimpahan Kewenangan Penandatanganan Pelayanan Perizinann dan Non Perizinan di Kota Bogor.

Kedua peraturan Walikota Bogor di atas untuk memenuhi Pasal 14 ayat (2) PP No.19 Tahun 2008 yaitu menyangkut kedudukan dan tanggung jawab Camat, sedangkan Pasal 15 ayat (1) dan (2) menyangkut Tugas Umum Pemerintahan yang dilaksanakan Camat dan kewenangan pemerintahan yang dilimpahkan Bupati/Walikota untuk menangani sebagian urusan otonomi daerah.

\section{Cara Untuk Mencapai Tujuan}

Untuk mewujudkan kedua tujuan seperti diutarakan di atas, itulah makna implementasi kebijakan PP No. 19 Tahun 2008 dalam penelitian ini, dan untuk mengetahui cara mencapai kedua tujuan dimaksud maka perlu digambarkan pada Gambar 5.

Sesuai dengan gambar proses pencapaian tujuan kebijakan, merupakan wujud implementasi kebijakan dalam penelitian ini dapat diuraikan indikator dari cara mewujudkan tujuan kebijakan yaitu:

1. Siapa yang menjadi pelaksana atau implementor kebijakan

Ada dua (2) hal terkait dengan pelaksana atau implementor kebijakan, pertama adalah pembuat kebijakan, kedua adalah pelaku atau pelaksana kebijakan. Terkait dengan PP No.19/2008 tentang kebijakan kecamatan, maka sebagai pembuat kebijakan adalah Kementerian Dalam Negeri Cq. Direktorat Jenderal Pemerintahan Umum (Ditjen PUM).

Apabila hirarkhi pembuatan dan pelaksanaan kebijakan tentang kecamatan ini digambarkan, maka

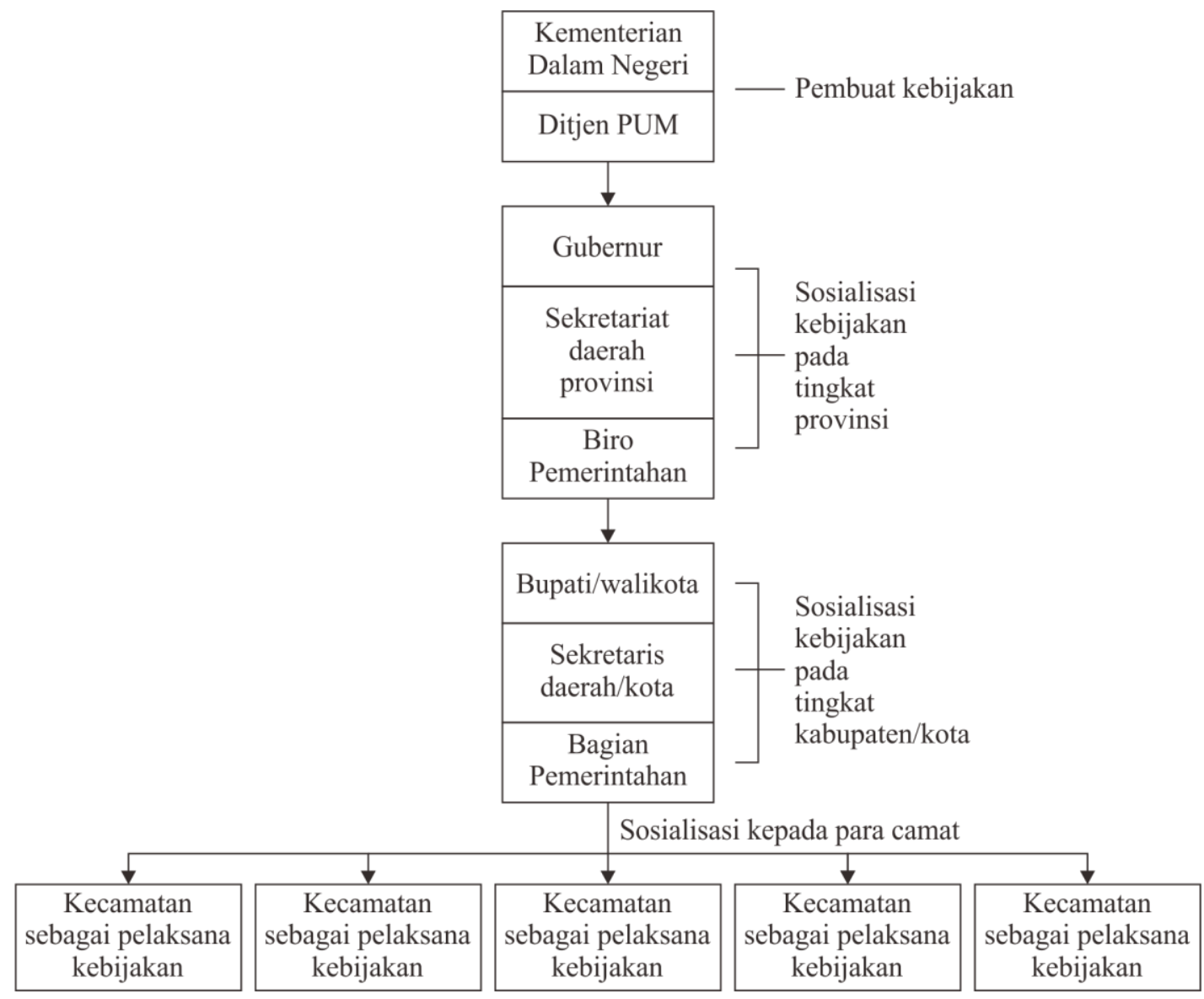

Gambar 6. Hirarki pembuatan dan pelaksanaan kebijakan tentang kecamatan 
Tabel 2. Penyediaan Dana/Anggaran

\begin{tabular}{|c|c|c|c|}
\hline Tahun & $\begin{array}{c}\text { Anggaran yang } \\
\text { disediakan }\end{array}$ & Realisasi & Persentase $(\%)$ \\
\hline $\begin{array}{l}\text { 1. Kecamatan Bogor Selatan } \\
2009 \\
2010 \\
\end{array}$ & $\begin{array}{r}\text { Rp 614.053.000,- } \\
\operatorname{Rp} 1.937 .895 .726,- \\
\end{array}$ & $\begin{array}{r}\operatorname{Rp} 614.053 .000,- \\
\operatorname{Rp} 1.926 .890 .803,- \\
\end{array}$ & $\begin{array}{r}100 \\
99,43 \\
\end{array}$ \\
\hline $\begin{array}{l}\text { 2. Kecamatan Bogor Barat } \\
2009 \\
2010\end{array}$ & $\begin{array}{r}\text { Rp 2.593.241.000,-- } \\
\operatorname{Rp} 11.937 .895 .726,-\end{array}$ & $\begin{array}{r}\text { Rp 2.562.071.660,-- } \\
\text { Rp 10.318.651.552,-- }\end{array}$ & $\begin{array}{r}100 \\
99,43 \\
\end{array}$ \\
\hline $\begin{array}{l}\text { 3. Kecamatan Bogor Tengah } \\
2010\end{array}$ & Rp. 1.566.433.000,- & Rp. 1.566.433.000,- & 100 \\
\hline
\end{tabular}

nampak seperti pada Gambar 6.

Sesuai dengan Gambar 6, maka kebijakan tentang Kecamatan sebagaimana ditetapkan dalam PP No.19/2008 secara berjenjang diteruskan sampai ke tingkat kecamatan sebagai pelaksana kebijakan.

Penyediaan Dana/Anggaran

Terkait dengan penyediaan dana/anggaran dalam rangka implementasi PP No.19/2008 sebagai kebijakan tentang kecamatan dapat dijelaskan sebagai berikut: pertama, pengimplementasian kebijakan PP No.19/2008 terkait dengan sosialisasinya untuk masing-masing tingkat pemerintahan. Penyediaan dana/anggaran untuk sosialisasi dimaksud dalam penelitian ini tidak diketahui dan tidak dikemukakan. $K e d u a$, penyediaan dana/anggaran untuk pencapaian tujuan yang meliputi:

a. Pelaksanaan tugas-tugas umum pemerintahan, dan

b. Pelaksanaan pelimpahan kewenangan dalam rangka otonomi daerah.

Terhadap kedua kegiatan dimaksud yang diterjemahkan dalam berbagai kegiatan oleh masingmasing kecamatan menyediakan dana/anggaran terdapat pada Tabel 2 .

Terkait dengan penyediaan dana/anggaran di atas pada masing-masing kecamatan (tiga kecamatan) tidak terlepas sebagai suatu bentuk perubahan yang sangat esensial yaitu "menyangkut kedudukan tugas pokok dan fungsi kecamatan yang sebelumnya merupakan perangkat wilayah dalam kerangka asas dekonsentrasi menjadi perangkat daerah dalam kerangka asas desentralisasi".

Disamping itu, Camat sebagai perangkat daerah juga mempunyai kekhususan dibandingkan dengan perangkat daerah (SKPD) lainnya dalam pelaksanaan tugas pokok dan fungsinya untuk mendukung pelaksanaan asas desentralisasi, yaitu:

a. Adanya suatu kewajiban Camat mengintegrasikan nilai-nilai sosio-kultural.

b. Menciptakan stabilitas dalam dinamika politik, ekonomi dan budaya.

c. Mengupayakan terwujudnya ketentraman dan ketertiban wilayah sebagai perwujudan kesejahteraan rakyat serta masyarakat.

d. Membangun integritas wilayah, dalam kaitan ini, Camat selain memberikan pelayanan kepada masyarakat, juga melakukan tugas-tugas pembinaan wilayah.

2. Kelompok Sasaran

Secara normatif sebenarnya kelompok sasaran PP No. 19 Tahun 2008 ini adalah Kecamatan. Artinya, sebagaimana diuraikan di atas, bahwa PP No.19 Tahun 2008 adalah sebagai pedoman yang harus dirujuk dalam pembentukan suatu kecamatan baru atau pemekaran dan sebagai pedoman atau dasar hukum bagi Bupati/Walikota dalam mengatur tugas pokok dan fungsi kecamatan. Dalam kaitan tugas pokok dan fungsi kecamatan ini Camat sebenarnya sebagai alat untuk menjangkau masyarakat. Oleh karena itu, kelompok sasaran yang sesungguhnya adalah masyarakat, yang secara administratif tertata dalam Kelurahan di wilayah Kota dan desa di wilayah kabupaten. Hal ini, sebenarnya tercakup dalam salah satu tugas umum pemerintahan yaitu: "Camat membina penyelenggaraan pemerintahan desa dan/atau kelurahan”. (Pasal 15 PP No.19/2008).

Disamping Camat membina penyelenggaraan Pemerintahan desa dan/atau kelurahan, juga Camat "mengkoordinasikan kegiatan pemberdayaan masyarakat". Itulah sebabnya dengan berpijak pada kedua tugas pokok dan fungsi ini, penelitian ini berkesimpulan "bahwa camat itu adalah instrumen atau alat pemerintah kabupaten/kota untuk menjangkau masyarakat sebagai sasaran pembangunan yang dilaksanakan", sebagaimana disebutkan dalam umum pemerintahan dan otonomi daerah.

\section{Bagaimana Program Dilaksanakan (Manajemen)}

Terkait dengan "bagaimana program dilaksanakan"? atau dengan perkataan lain "bagaimana manajemen dilaksanakan untuk mewujudkan tujuan yang telah ditetapkan"

Pelaksanaan program di tingkat kecamatan tidak dapat dipisahkan dari aturan normatifnya, yang secara garis besar dapat diuraikan sebagai berikut:

a. UU No.32 Tahun 2004 tentang Pemerintahan Daerah.

Melalui UU ini peranan Pemerintahan Daerah diharapkan dapat mewujudkan prinsi-prinsip God Governance (Tatakelola pemerintahan yang baik) 


\begin{tabular}{|l|l|l|}
\hline $\begin{array}{l}\text { Visi \& Misi } \\
\text { Jawa Barat }\end{array}$ & $\begin{array}{l}\text { Tercapainya masyarakat Jawa Barat yang mandiri, } \\
\text { dinamis, dan sejahtera }\end{array}$ \\
\hline & Dengan 5 (lima) misi & \\
\hline
\end{tabular}

\begin{tabular}{|l|l|l|}
\hline $\begin{array}{l}\text { Visi } \\
\text { Kota Bogor }\end{array}$ & $\begin{array}{l}\text { Kota jasa yang nyaman dengan masyarakat } \\
\text { madani }\end{array}$ \\
& \multicolumn{2}{|l|}{ Dengan 4 (empat) misi } \\
\hline
\end{tabular}

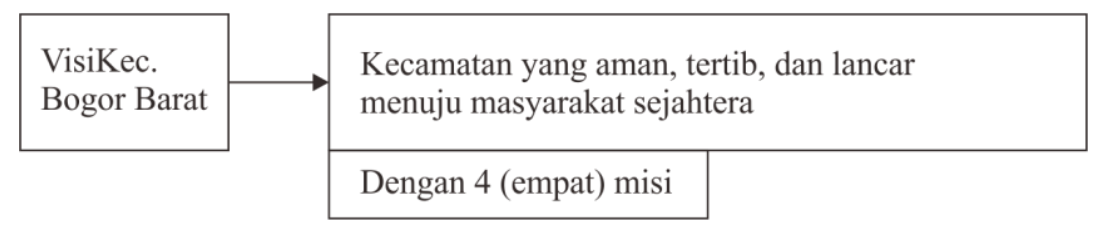

Gambar 7. Penyusunan program dan kegiatan di tingkat Kecamatan se-Kota Bogor

dalam penyelenggaraan pemerintahan daerah dengan pemberian otonomi daerah sejak tahun 2001. Salah satu tujuan pemberian otonomi darah adalah untuk meningkatkan kualitas pelayanan masyarakat. Untuk itu Pemerintah Kecamatan dituntut untuk:

1. Memahami lebih baik kebutuhan masyarakat yang terdiri dari berbagai kalangan dan lapisan masyarakat.

2. Melibatkan seluruh unsur masyarakat dalam proses pembangunan secara partisipatif.

3. Menyelenggarakan tata pemerintahan kecamatan secara partisipatif.

b. UU No. 25 Tahun 2004 tentang Sistem Perencanaan Pembangunan Nasional (SPPN).

Implementasi UU ini di tingkat kecamatan yaitu menyusun Rencana Pembangunan Jangka Menengah SKPD, yang selanjutnya disebut Renstra SKPD, yang merupakan dokumen perencanaan SKPD untuk periode lima (5) tahun. Penjabaran dari Renstra SKPD tersebut berupa Rencana Pembangunan Satuan Perangkat Daerah yaitu berupa Renja SKPD sebagai dokumen perencanaan SKPD untuk periode satu (1) tahun.

Berdasarkan amanat UU No.25/2004 tentang SPPN, maka semua kecamatan yang ada di Kota Bogor, menyusun penjabaran dari Renstra SKPD untuk tahun 2010-2014 sebagai berikut:

\section{Kecamatan Bogor Barat}

Dalam realitasnya, semua kecamatan yang ada di Kota Bogor dalam menetapkan program dan kegiatannya secara normatif merujuk pada aturan atau ketentuan normatif di atasnya.

Sebagai contoh, kecamatan Bogor terlebih dahulu menetapkan visi dan misinya yang merupakan derivasi dari Visi dan Misi Kota Bogor, begitu juga visi dan misi kota Bogor merupakan derivasi dari visi dan misi Provinsi Jawa Barat.

Sesuai dengan uraian di atas, maka secara berjanjang dijelaskan secara visual seperti pada Gambar 7. Penyusunan program dan kegiatan di tingkat Kecamatan se-Kota Bogor, mengikuti pula seperti Gambar 7.

\section{SIMPULAN}

Merujuk pada data, informasi dan analisis yang dikemukakan, maka dapat disimpulkan bahwa "Implementasi Kebijakan Peraturan Pemerintah Nomor 19 Tahun 2008 tentang Kecamatan di Kota Bogor, telah diimplementasikan oleh Walikota Bogor dalam menata eksistensi kecamatan di Kota Bogor. Pengimplementasian PP No.19 Tahun 2008 tersebut, ditetapkan lebih lanjut dalam bentuk Peraturan Walikota Nomor 54 Tahun 2010 tentang Tugas Pokok, Fungsi, Tata Kerja dan Uraian Tugas Jabatan Struktural di Lingkungan Kecamatan dan Nomor 10 Tahun 2010 tentang Pelimpahan Kewenangan. meliputi:

Pengimplementasian kebijakan dimaksud

1. Tugas Umum Pemerintahan, yang terdiri dari:

a. Mengkoordinasikan kegiatan pemberdayaan masyarakat, 
b. Mengkoordinasikan upaya penyelenggaraan ketentraman dan ketertiban umum,

c. Mengkoordinasikan penetapan dan penegakan peraturan perundang-undangan,

d. Mengkoordinasikan pemeliharaan prasarana dan fasilitasi pelayanan umum,

e. Mengkoordinasikan penyelenggaraan kegiatan pemerintahan di tingkat kecamatan,

f. Membina penyelenggaraan pemerintahan desa dan/atau kelurahan,

g. Melaksanakan pelayanan masyarakat yang menjadi ruang/lingkup tugasnya dan/atau yang belum dapat dilaksanakan pemerintahan desa atau kelurahan.

2. Tugas yang dilimpahkan terdiri dari:

a. perijinan dibidang gangguan atau $\mathrm{HO}$,

b. rekomendasi dibidang ijin-ijin penelitian ke masyarakat dan pendidikan,

c. koordinasi dibidang Site Plann dan SKPR, ijin kegiatan keamanan.

d. pembinaan dibidang lembaga kemasyarakatan (LPM, RT, RW) dan para Lurah dan Staf,

e. pengawasan dibidang ijin gangguan / $\mathrm{HO}$, bidang industry dan perdagangan,

f. fasilitasi diberikan kepada Camat, Sekcam berupa kendaraan roda 4 dan kendaraan roda 2 kepada para Kepala Seksi,

g. penetapan antara lain Surat Keputusan Camat, Surat Perintah Camat dan Surat Tugas Camat,

h. Kewenangan lainnya antara lain pembuatan akta jual beli, pembuatan akta waris.

3. Pengimplementasian kebijakan dimaksud adalah untuk mewujudkan Visi Kota Bogor yaitu "Kota Jasa yang Nyaman Dengan Masyarakat Madani" dan Visi masing-masing Kecamatan antara lain "Kecamatan yang Aman, Tertib dan Lancar Menuju Masyarakat Sejahtera" (Visi Kec. Bogor Barat), yang selanjutnya diwujudkan ke dalam misi, tujuan dan sasaran masing-masing kecamatan, d. Selanjutnya, misi, tujuan dan sasaran tersebut ditindaklanjuti ke dalam program dan kegiatan setiap tahun yang ditetapkan dalam dokumen perencanaan yang disebut dengan Rancangan Kerja Pembangunan Daerah (RKPD) masing-masing kecamatan. Dalam dokumen RKPD inilah terdapat program, kegiatan, output dan outcome serta biaya/anggaran yang disediakan dan dilaksanakan setiap tahunnya.

\section{Rekomendasi}

Terkait dengan simpulan sebagaimana dikemukakan, maka beberapa hal dapat disarankan sebagai berikut:

1. Pelaksanaan Tugas Umum Pemerintahan dan Tugas yang dilimpahkan oleh Walikota Bogor kepada para Camat, sebagaimana diamanatkan PP No.19 Tahun 2008, yang selanjutnya diatur dan ditetapkan dalam Peraturan Walikota Nomor 54 dan Nomor 10 Tahun 2010, masih perlu disosialiasikan baik oleh Pemerintah, Pemerintah
Daerah Provinsi, Kabupaten/Kota agar Camat dan perangkatnya dalam mengkoordinasikan:

a. Kegiatan pemberdayaan masyarakat,

b. Upaya penyelenggaraan ketentraman dan ketertiban umum,

c. Penetapan dan penegakan peraturan perundang-undangan,

d. Pemeliharaan prasarana dan fasilitasi pelayanan umum,

e. Penyelenggaraan kegiatan pemerintahan di tingkat kecamatan, dapat terlaksana sesuai dengan:

1) Standar Prosedur Operasionalnya (SOP),

2) Obyek dan kegiatannya serta anggaran yang disediakan,

3) Output dan outcome yang ditetapkan.

2. Camat beserta perangkatnya, dalam melaksanakan tugas umum pemerintahan dan tugas yang dilimpahkan, harus melaporkan secara tertulis kepada Walikota Bogor secara berkala dan teratur, menyimpan dokumen laporan tersebut sehingga dapat diketahui tugas-tugas apa saja yang belum dilaksanakan, mengalami kesulitan, sehingga dapat diketahui di lini mana yang perlu dibenahi dan ditingkatkan.

3. Badan Perencanaan Pembangunan Daerah (Bappeda) Kota Bogor dan Bagian Pemerintahan harus melakukan evaluasi terhadap tugas umum pemerintahan dan tugas yang dilimpahkan kepada para Camat yang ada di Kota Bogor, untuk mengetahui:

a. Sejauhmana Visi, misi, tujuan dan sasaran Kota Bogor terakomodasi dan terlaksana di masing-masing Kecamatan,

b. Bagaimana pelaksanaannya dan kendala yang dihadapi masing-masing kecamatan.

\section{DAFTAR PUSTAKA}

Buku

Badan Penelitian dan Pengembangan Departemen Dalam Negeri (1990), Merangkai Masa Depan Otonomi Daerah, (kumpulan Makalah).

Dunn, William N. (2003), Pengantar Analisis Kebijakan Publik, Yogyakarta: Gadjah Mada University Press, Cet. Kelima, (terjemahan)

Islamy, Irfan M, (1992), Prinsip-prinsip Perumusan Kebijaksanaan Negara, Jakarta: Bumi Aksara. Cet. keenam.

Koswara, E., (2001), Teori Pemerintahan Daerah, (Diktat)

Purwanto, Erwan Agus, dan Sulistyastuti, Dyah Ratih, Yogyakarta: Penerbit Gava Media, Cet. 1.

Sugiyono (2013), Metode Penelitian Administrasi, Bandung: Alfabeta, cet. ke 21.

Suharto, Edi, (2010), Analisis Kebijakan Publik, Bandung: Penerbit CV. Alfabeta, Cet. Keenam.

Sujamto, (1996), Membedah Otonomi Daerah, Suatu Evaluasi Atas Undang-Undang No. 5 Tahun 1974, Badan Penelitian dan Pengembangan Depdagri (Kumpulan Makalah). 
Suryaningrat, Bayu (1980), Mengenal Ilmu Pemerintahan, Jakarta: Aksara Baru.

Wibawa, Samodra, dkk., (1994), Evaluasi Kebijakan Publik, Jakarta: PT. Raja Grafindo Persada, Cet. Pertama.

\section{Dokumen}

Undang-Undang Dasar Negara Kesatuan Republik Indonesia Tahun 1945.

Nomor 32 Tahun 2004 tentang Pemerintahan Daerah.

Peraturan Pemerintah Nomor 19 Tahun 2008 tentang Kecamatan.

\section{Lain-lain}

Puslitbang Pembangunan \& Keuangan Daerah, Akselerasi Kecamatan Sebagai Pusat Pertumbuhan di Wilayah Perkotaan, Hasil Penelitian Tahun 2011. 


\section{Lampiran Gambar 8}

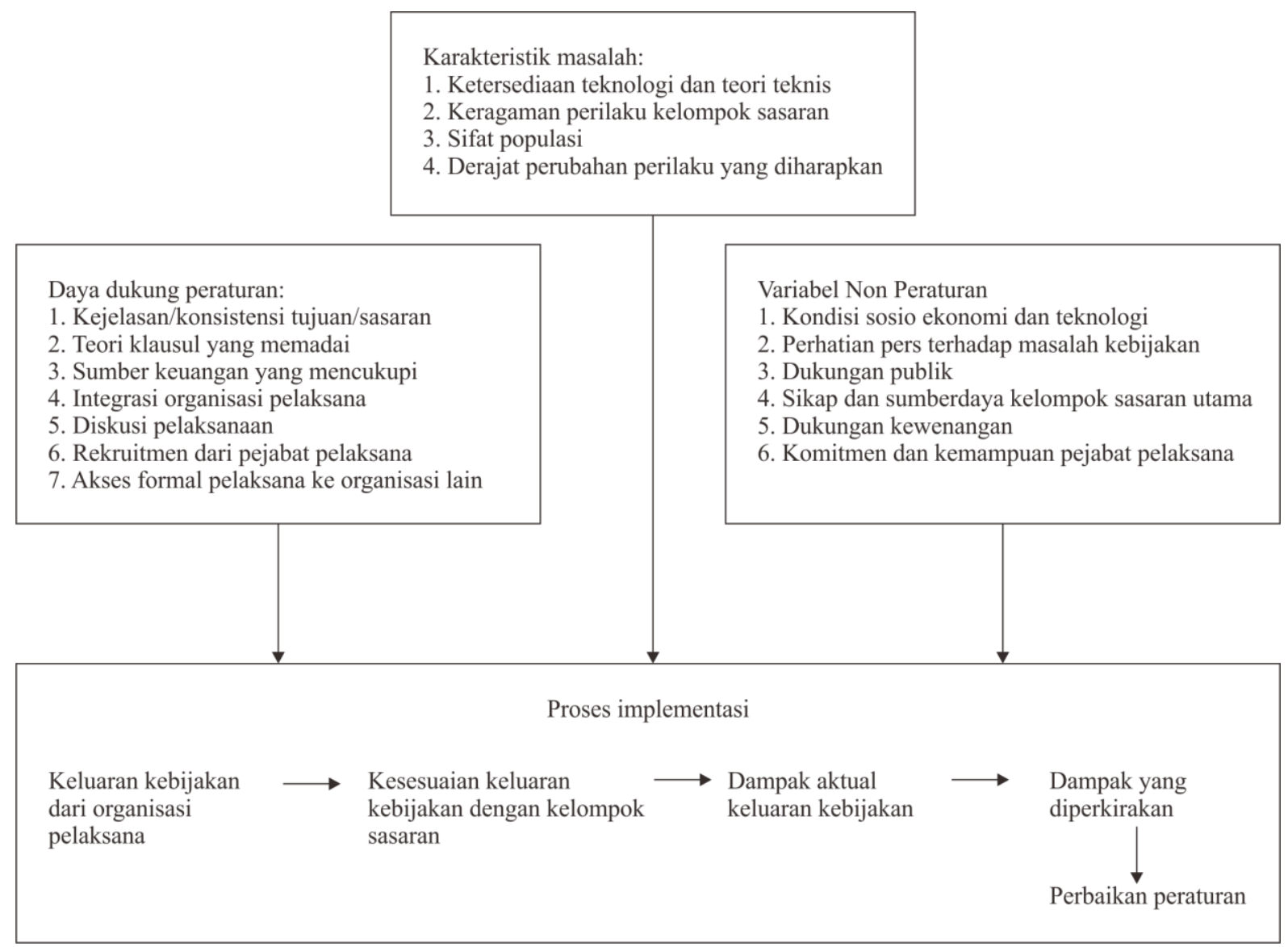

Gambar 8. Implementasi kebijakan model Sabatier dan Mazmanian (1986) dalam Wibawa (1994) 
